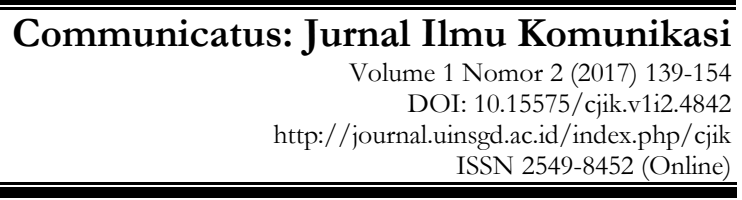

\title{
Efektivitas Komunikasi Dakwah di Pesantren MQ dalam Merubah Akhlak Santri
}

\author{
Agus Sudiansyah ${ }^{1 *}$ \\ ${ }^{1}$ Yayasan Darut Tauhid, Bandung \\ *email : agussudiansyab31@gmail.com
}

\begin{abstract}
Indonesia has different types of educational institutions including a state owned institution and a private one. However, recently, several types of educational institutions in Indonesia have some attention from the society in terms of the development of behavioral character of the youth that tend to be degrading. Effective communication of dakwah (preaching) at Pesantren MQ Tebuireng (MQ Tebuireng Islamic Boarding School) as well as akblak(behavior) education is believed to be able to improve the behavior or so called akblak of the Indonesian youth to be better. It can be seen from this study, a study at Pesantren MQ Tebuireng aimed at finding the influence and correlation between the effectivity of communication of dakwah and akblak education towards students. This study is a Quantitative study. The data in this study are obtained through survey using a proportional stratification sample tehnique towards 172 students at Pesantren MQ Tebuireng. The study shows that there is a simultaneous influence between an effective communication of dakwah and akblak education towards students where Fcount of $18.009>$ Ftable of 3.05. However, there is also a correlation with $r$ value of .749 . According to Priyato, the $r$ value of .60 - .799 shows a strong correlation, i.e. between the effectivity of communication of dakwah and akblak education towards students.
\end{abstract}

Keywords: the effectivity of communication of dakwab; akblak education; students' akblak.

\begin{abstract}
ABSTRAK
Indonesia memilki bebearapa lembaga pendidikan, yakni lembaga pendidikan milik pemerintah dan lembaga milik per orangan, sedangkan sekarang beberapa lembaga pendidikan di Indonesia mendapat sorotan dari masyarakat mengenai pengembangan karakter tingkah laku generasinya yang mulai menurun. Komunikasi dakwah yang efektif di Pesantren MQ Tebuireung dan pembinaan akhlak diyakini dapat meningkatkan tingkah laku atau akhlak generasi di Indonesia menjadi lebih baik. Terbukti hasil penelitian di Pesantren MQ Tebuireung dengan tujuan ingin mengetahui pengaruh dan hubungan efektivitas komunikasi dakwah dan pembinaan akhlak terhadap akhlak santri. Penelitian ini merupakan penelitian Kuantitatif. Data dikumpulkan melaui survei dengan teknik sampel stratifikasi proporsional terhadap santri di Pesantren MQ Tebuirung berjumlah 172 santri. Hasil penelitian menunjukan terdapat pengaruh secara simultan dengan F Hitung 18,009> F Tabel 3,05, komunikasi dakwah yang efektif dan pembinaan akhlak terhadap akhlak santri, dan terdapat hubungan atau korelasi dengan sederhana dengan nilai 0,749 , menurut Priyato nilai 0,60-0,799 sangat kuat hubungannya dari efektivitas komunikasi dakwah dan
\end{abstract}


Agus Sudiansyah

pembinaan akhlak terhadap akhlak santri.

Kata Kunci : komunikasi dakwah; pembinaan akhlak; akhlak santri

\section{PENDAHULUAN}

Pertama latar belakang penelitian, Masyarakat kini, seperti dilukiskan Maureen, bukan lagi masyarakat seperti sepuluh atau dua puluh tahun yang lalu. Pola hidupnya telah berubah. Pola-pola interaksinya bergeser mengikuti arus perubahan lingkunagn sosial budaya yang pada sekitar dua dekade terakhir memperlihatkan tengah berlangsungnya proses tranformasi sosial yang sangat berarti. Perubahan dasyat telah mempengaruhi selera dan cara-cara menjalani aktivitas sehari-harinya, termasuk bergesernya pola-pola pemanfaatan waktu sejak bangun hingga tidur kembali (Maureen, 1996:1).

Maraknya penurunan moral pada sebagian lembaga pendidikan dan rendahnya respon generasi muda terhadap tuntunan .. menyebabkan kekhawatiran orang tua dan berkurangnya minat dan kepercayaan masyarakat terhadap beberapa lembaga pendidikan, untuk itu jawaban dari kekhawatiran orang tua bisa terjawab dengan adanya pesantren, akan tetapi masih banyak pesantren yang menerapkan sistem komunikasi dakwah yang lama yang terkesan kaku, bahkan sekarang terdengar marak/viral pesantren menggunakan hukuman dengan kekerasan sebagai sarana membina santri, hal ini menyebabkan munculnya anggapan kurang baik sebagian orang terhadap pesantrendan tidak sedikit beberapa pesantren yang gulung tikar karena kurangnya minat masyarakat, adapun demikian masih banyak pesantren yang bertahan bahkan lebih banyak diminati walaupun usianya sudah lama, termasuk salah satunya Pesantren salafiyah Madrasatul Qur'an Tebuireung yang berada di Jombang Jawa Timur.

Kenapa masih banyak pesantren-pesantren yang eksis pada saat sekarang bahkan banyak peminatnya, salah satunya karena diterapkannya sistem yang dinamis, dimana sistem ini terus berubah mengikuti sesuai perkembangan jaman, salah satunya dengan cara mengajar yang lebih efektif, cara memberikan pembinaan pada santri yang lebih teratur dan terarah, sesuai dengan berpedoman pada al-Qur'an dan al-Hadist, terutama pada saat sekarang salah satu pesantren yang banyak diminati oleh khalayak adalah pesantren berbasis al-Qur'an atau menghafal al-Qur'an, salah satunya Pondok Pesantren Madrasatul Qur'anTebuireung Jombang.

Pondok Pesantren Madrasatul Qur'an ini adalah pesantren berbasis salafiyah yang mengedepankan hapalanAl-Qur'an, tidak kurang setiap tahunnya Pondok Pesantren ini meluluskan 20 santri hafidz Qur'an 30 Juz dan kurang lebihnya 2-3 santri wisuda karena menyelesaikan hafalan Qur'an dengan Qira'ah Sab'ah, dan hampir ratusan santri wisuda Binadhar (Fasih dalam Membaca alQur'an). 
Efektivitas Komunikasi Dakwah di Pesantren MQ dalam Merubah Akhlak Santri

Mengenai sejarah dari Pesantren MQ Tebuireung Jawa Timur,pesantren ini merupakan pelebaran dari Pondok yang tergolong tua dan terkenal sampai saat ini yakni pondok pesantren Tebuireng yang didirikan oleh KH. Hasyim Asy'Ari yang sekarang diteruskan oleh keturunannya. Dari keturunan beliau ini, ada yang kemudian membentuk dan mendirikan tempat khusus bagi santri yang mahir dan hafal Al-Qur'an, yakni Madrasah Al-huffadz yang didirikan pada Tahun 1971 M, yaitu bagi santri yang memiliki tujuan untuk menghafal AlQur'an yang kemudian berkembang pesat. Sehingga, pada tahun 1982 dimandirikan dan kini menjadi Madrasatul Qur'an. Madrasatul Qur'an lahir melalui beberapa proses hasil musyawarah dari Sembilan kiai [antara lain: KH. Mansyur (Pacul Gowang), KH.Kholil (Sukopuro), KH. Shobari (Bogem) KH. Adlan Aly (Cukir), KH. Mahfudh Anwar (Seblak), KH. Ya'kub (Bulurejo), KH. Syan suri Badhawai (Tebuireng), KH. Muhammad Yusuf Masyhar (Jombang), KH. Yusuf Hasyim (Tebuireng)], dan pengasuh Pondok pesantren Tebuireng KH. Yusuf Hasyim. Hal tersebut baru terealisasi atas gagasan KH.M. Yusuf Masyhar, cucu menantu dari almarhum Hadratusy SyaikhKH. Hasyim Asy'ari pendiri pondok pesantren Tebuireng dan HA. Hamid Baidlowi, (Dokumen PP MQ: 2018:58).

Dasar dan tujuan didirikannya Pesantren MQ Tebuirung adalah : 1. Sesuai dengan fungsi Al-Qur'an terhadap orang-orang yang bertaqwa, Madrasatul Qur'an sebagai suatu institusi pendidikan dan pengajaran ingin membentuk dan menjadikan manusia yang muttaqin melalui Al-Qur'an. 2. Berkaitan dengan pemikiran diatas, maka apa yang dilakukan Madrasatul Qur'an ini adalah sematamata untuk memenuhi kewajiban sebagai hamba terhadap sesamanya. 3. Di Indonesia belum banyak badan dan lembaga pendidikan Al-Qur'an yang mengedepankan misi lafdhon(Hafal secara menyeluruh lafadz al-Qur'an), wa ma'nan(Memahami isi kandungan al-Qur'an) wa 'amalan (mengamalkan isi kandungan al-Qur'an), bentuk kajiannya yang sistematik dan klasikal. Untuk itu, Madrasatul Qur'an berupaya untuk mengatisipasi hal yang demikian, terutama ditekankan pada isi program pendidikan dan pengajarannya, yaitu Al-Qur'an dan khususnya dari segi qiro atnya (bacaanya).

Pimpinan saat ini adalah KH.Gus Didi (Putra dari Almarhum Hadratus SyaikhKH. Yusuf Mashar) menujukan perbedaannya dengan pesantren lain yaitu menerapkan pola komunikasi dakwah salafi denganmisi "profetis"-nya, untuk mengajarkan Al-Qur'an dan menyemaikan nilai-nilai Al-Qur'an dalam kehidupan sehari-hari. Dengan penuh ketekunan \&keikhlasan ngawuruk ngaji (dibaca: ta'lim, tarbiyah dan ta'dib) begitu juga dengan penerapan Qonun(aturan-aturan yang telah dibuat sejak dulu terkait pesantren) dan menerapkan system keberkahan dalam setip elemen yang ada di pesantren, baik ta'drim antara santri dengan Ustadz maupun Ustadz dengan Ustadz, dijadikan sebagai alat utama dalam pembentukan karakter akhlak santri, berikut juga sebagai jawaban dari tantangan globalisasi terhadap penerapan penyampain dakwah dilingkungan pesantren 
Agus Sudiansyah

diera ini.

Kajian sejenis yang terkait dengan paradigm, pola dan bentuk komunikasi dakwah bisa dilihat dalam beberapa penelitian yang telah dilakukan sebelumnya, yaitu tentang Penelitian terkait dengan paradigma, pola dan bentuk komunikasi dakwah yaitu, Paradigma Baru Dakwah Islam: Perspektif Komunikasi Massa (Rachmiatie, 2002), Dinamika Dakwah dalam Komunikasi dan Penyiaran Islam; Pendekatan Historisasi, Formulasi dan Aplikasi (Syukur, 2014) dan Komunikasi Dakwah Efektif dalam Perspektif Alquran (Markarma, 2014). Pola dan model dakwah yaitu, Pola Komunikasi Dakwah KH. Abdullah Gymnastiar dan KH. Jalaluddin Rakhmat (Ma'arif, 2009), Dakwah Kolaboratif: Model Alternatif Komunikasi Islam Kontemporer (Bachtiar, 2013), adapun penelitian yang mengkaji strategi komunikasi dakwah adalah, Strategi Komunikasi Dakwah Band Wali dalam Lagu Cari Berkah (Permana, 2013) dan Strategi Komunikasi Dakwah dalam Pembinaan Mental Narapidana (Ariyanto, 2019).

Penelitian yang mengkaji komunikasi dakwah kaitannya dengan media yaitu, Disfungsi Tradisi Lisan Melayu Jambi Sebagai Media Komunikasi Dakwah. (Mursyidah, 2012), Membangun Komunikasi Dakwah Melalui Media Massa. (Mursyidah, 2010) dan Dakwah dan Tantangannya dalam Media Teknologi Komunikasi (Rajab, 2014). Sedangkan penelitian terkait komunikasi dakwah dan politik diantaranya yaitu, Komunikasi Politik Dakwah Partai Keadilan Sejahtera pada Pemilu legislatif 2009 (Aminulloh, 2010) dan Urgensi Komunikasi Politik Dakwah (Suharto, 2013).

Kajian-kajian komunikasi dakwah tersebut banyak berorientasi pada paradigm, pola, bentuk, strategi, politik maupun dakwah dengan pendekatan media, adapaun dalam penelitian ini lebih menitikberatkan kepada efektifitas komunikasi dakwah, dengan objek kajian akhlaq santri.

Penelusuran singkat literatur yang berkaitan dengan masalah yang diangkat, Septimar Prihatini, dkk, (2013): Judul Pengembangan Model Penilaian Akblak Peserta Didik Madrasah Aliyah, variabelnya X1Pengembangan Model Penilaian X2 Akblak Peserta didik, hasil penelitian :- Instrumen tersusun melalui proses expert judgment, Focus Group Disscussion dan pengujian konstruk. Analisis faktor konfirmatori (CFA) berdasarkan data empiric, Grand Theory yang dipakai yaitu religiousity dari Glock and Stark. Hipotesis di uji oleh Misharyati adalah menggunakan purposive sampling. Sedangkan peneliti menggunakan uji $\mathrm{T}$ dan $\mathrm{F}$ dengan metode analisis jalur berganda (parth analysis). Jumlah sampel di MA Yogyakarta adalah 291 siswa dan 26 guru, Sedangkan di PP MQ Tebuireung 172.

Ketiga lokasi penelitian, Pondok pesantren Madarasatul Qur'an Tebuireung jl Iriyan Jaya No, 10 Jombang Jawa Timur indonesia. Keempat pertanyaan penelitian, 1. Bagaimana pengaruh komunikasi dakwah yang efektif di Pesantren MQ Tebuireung Jombang Jawa Timur dalam membina akhlak santri? 2. Bagaimana hubungan dan pengaruh pembinaan akhlak di Pesantren MQ 
Efektivitas Komunikasi Dakwah di Pesantren MQ dalam Merubah Akhlak Santri

Tebuireung Jombang terhadap akhlak santri? 3. Bagaimana hubungan dan pengaruh efektivitas komunikasi dakwah dan pembinaan akhlak secara simultan di Pesantren MQ Tebuireung Jombang terhadap akhlak santri?. Kelima metode penelitian, Model penelitian ini menggunakan pendekatan kuantitatif, karena pendekatan kuantitatif dapat menghasilkan data yang akurat setelah penghitungan yang tepat. Pendekatan kuantitatif merupakan salah satu pendekatan dalam penelitian yang lebih ditekankan pada data yang dihitung untuk menhasilkan penafsiran kuantitatif yang kokoh. Metode yang digunakan dalam penelitian ini adalah metode survei. Survei menggunakan kuesioner sebagai instrumen pengumpulan data. Tujuannya adalah memperoleh informasi dari sampel yang menjadi representasi populasi.

\section{HASIL DAN PEMBAHASAN}

Berdasarkan hasil penelitian terhadap 172 responden santri Pondok Pesantren MQ Tebuireung Jombang. Responden penelitian ini didominasi oleh responden santri berasal dari jawa timur yang berjumlah 70 respponden(40,7\%), santri berasal dari jawa tengah ` 15 responden(8,7\%), santri berasal dari jawa barat 35 responden $(20,4 \%)$, dan dari luar pulau jawa 42 responden $(24,4 \%)$. Dominasi santri berasal dari Jawa Timur ini sesuai dengan komposisi santri Pesantren Madarasatul Qur an Tebuireung Jombang. Tercatat total keseluruhan santri Pesantren Madrasatul Qur an Tebuireung jombang perbulan Juli 2018 ialah berjumlah 1721 santri, yang teridiri dari 1253 santri berasal dari Jawa Timur, 69 santri dari jawa tengah, 110 santri dari jawa barat, dan 289 santri berasal dari luar jawa.

Jadi dapat disimpulkan bahwa mayoritas responden dalam penelitian ini adalah santri berasal dari daerah jawa timur. Hal ini karena Pesantren Madrasatul Qur an Tebuireung berdomisili di daerah Jawa Timur dengan begitu kebanyakan masyarakat memondokan anaknya tidak jauh dari tempat tinggalnya, agar dengan alasan bisa dikunjungi, dan bisa terpantau diperkuat dengan pernyataan dari salah satu Pembina asrama dari komplek Jannatul Firdaus, Bapak Ade Fatulloh.

"kenapa kebanyakan dari daerah jawa timur? Karena letak domisili pesantren MQ Tebuirung berada di Jombang Jawa Timur, dan alasan orang tua memondokan anaknya tidak jauh dari tempat tinggalnya agar dapat mudah di kunjungi dan rata-rata orang jawa timur kesadaran untuk memondokan anaknya itu masib terbilang masib tinggi dibandingkan dengan daerah lain”.

Berdasarkan hasil penelitian untuk unit kelas terhadap 172 responden santri di Pesantren Madrasatul Qur an Tebuirueng Jombang, terdapat 88 responden (52\%) santri dari kelas Aliyah (SMA), 79 responden (46\%) santri dari kelas MTS (SMP), dan 4 responden (2,4\%) santri dari kelas PHQ. Menunjukan bahwa bahwa mayoritas responden dalam penelitian ini berasal dari santri yang sudah aliyah (SMA) berkisar 88 santri. Hal ini dikarenakan santri yang sudah 
Agus Sudiansyah

bersetatus aliyah (SMA) tingkat pemikirannya lebih dewasa, serta lebih lama tinggal di pesantren dibandingkan dengan siswa MTS (SMP). Dan lebih mengerti banyak terkait persoalan yang ada di pesantren.

Jika melihat data responden berdasarkan unit komplek Pesantren Madrasatul Qur an Tebuireung Jombang,terdapat 9 komplek dan dari setiap komplek diambil 20 responden 11,3\% dari komplek Maqomam Mahmuda, 19 responden 11,2\% dari komplek Munjalan Mubaroka, 19 responden 11,2\% dari komplek Mudkholan Karimah, 22 responden 12,7\% dari komplek Darussalam, 9 responden 5.1\% dari komplek Darul Muqoma, 2 responden 2,4\% dari kompleh Hufadz, 27 responden dari komplek Jannatul Firdaus, 28 responden 16,2\% dari komplek Maq'adu Shidqin, 24 responden 24,1\% dari komplek Maqomin Amin, jadi total kesluruhan responden 172 santri yakni 10\% dari 1721 santri yang berada di Pesantren Madrasatul Qur an Tebuireung Jombang.

Efektivitas komunikasi adalah tercapainya tujuan dalam menyampaikan informasi dan pesan, dengan mempunyai efek signifikan pada orang yang mendapatkan informasi pesan tersebut. Pembinaan akhlak banyak dilakukan oleh beberapa lembaga Pesantren, beberapa pesantren yang ada di Indonesia menunujukan hasil yang baik dalam membina akhlak para santrinya, salah satunya hasil penelitian di Pesantren Nurul Islam Kuantan Singingi Pekan Baru Riau menunujukan persentase rata-rata kuantitatif dengan nilai 82,44\% dimana nilai tersebut dapat dikategorikan baik yaitu 76-100\%, dalam membina akhlak santri. Selain itu penelitian di Pondok Pesantren Waria al Fatah Yogyakarta dengan metode kualitatif menunjukan mencapai tujuan yang baik dengan berubahnya perilaku santri waria menjadi pribadi yang baik.

Komunikasi yang efektif dioperasionalkan sebagai 1). Openes yaitu adanya keterbukaan komunikasi antara ustadz, pengurus dengan santri. 2). Supportiveness yaitu saling mendukung dari ustadz, pengurus, dan keluarga dengan santri dalam membina diri pada akhlak yang baik.3). Positiveness yaitu saling bersikap positif dalam memberikan pemikiran baik itu dari ustadz, teman, keluarga, dan lingkungan terhadap santri. 4). Emphaty yaitu memahami sifat orang lain, yakni saling membantu satu sama lain dalam meningkatkan kualitas diri ke arah yang lebih baik. 5). Equality yaitu kesetaraan, yakni tidak membedakan santri satu sama lain dari segi duniawi. (Devito dalam Kiryantono, 2012)

Dakwah sebagai bentuk aktivitas komunikasi, akan memandang efektivitas proses dakwah dalam bingkai efektivitas komunikasi. Salah satu ciri penting komunikasi efektif adalah adanya efek signifikan pada diri komunikan. Dalam perspektif perubahan individu ataupun kelompok, efek itu bisa terjadi diwilayah kognitif, afektif, maupun psikomotorik. Wilayah-wilayah perubahan itu pula yang dapat dijadikan ukuran tinggi rendahnya efektivitas dalam proses dakwah. Dalam berdakwah, para da'i atau mubalig umumnya memanfaatkan kemampuan komunikasi yang dimilkinya. Dakwah bil-lisan seolah menjadi satu-satunya 
saluran yang mereka gunakan dalam menyampaikan pesan-pesan Tuhan untuk dijadikan pegangan dalam kehidupan. Para da'i ataupun mubalig sesungguhnya tahu kalau ada pendekatan lain yang dapat digunakan dalam mengajak orang berbuat baik, seperti pendekatan bil hal, atau pendekatan uswah (Muhtadi, 2012).

Pendekatan bil lisan, bil hal, danuswah merupakan bentuk dari pembinaan akhlak dan keagamaan yang biasanya dilakukan oleh pesantren, dan penelitian ini lebih fokus terhadap pembinaan, dengan melalui 3 proses pembinaan menurut Ahmad D. Marimba (Marimba, 1989, hlm, 76-80), yaitu 1) Pembiasaan, 2) Pembentukan pribadi, sikap dan mental, 3)Pembentuk Kerohanian yang Luhurakhlak terhadap santri yang menimba ilmu di pesantren.

Tolak ukur akhlak meurut Moh Ardani (dalam Ardani, 2005, hlm, 70) terdapat 2 unsur akhlak, 1) Akhlak baik terhadap Allah SW'T sang pencipta, dengan meliputi, a. Beribadah. b. Bertaubat. c. Bersabar. d. bersyukur. e. bertawakal. f. Berprasangka baik kepada Allah. g. bersikap takut pada Allah. 2) Akhlak baik terhadap makhluk Allah SWT, dengan meliputi, a. Mengikuti sunnah Nabi Muhammad SAW, b. Berbuat baik pada diri sendiri, c. Berbuat baik pada guru, d. Berbuat baik pada orang tua, e. Berbuat baik pada teman, f. Berbuat baik pada tetangga, g. Berbuat baik pada masyarakat, h. Berbuat baik terhadap lingkungan.

Model dasar dalam ilmu komunikasi yang dipilih adalah teori model jarum hipodermik, penelitian dengan model ini dilakukan oleh Hovland dkk. Untuk meneliti pengaruh propaganda sekutu dalam mengubah sikap. Model ini mempunyai asumsi bahwa komponen-komponen komunikasi (komunikator, pesan, dan media) amat perkasa dalam mempengaruhi komunikasi. Disebut jarum hipodermik karena dalam model ini dikesankan seakan-akan komunikasi "disuntikan" langsung kedalam jiwa komunikan. Sebagaimana obat disimpan dan disebarkan dalam tubuh sehingga terjadi perubahan dalam system fisik, begitu pula pesan-pesan persuasive mengubah sistem psikologis (Rakhmat, 2015: 114).

Model ini juga sering disebut "bullet Theory" (teori peluru) karena komunikan dianggap secara pasif menerima berondongan pesan-pesan komunikasi. Bila kita menggunakan komunikator yang tepat, pesan yang baik, atau media yang benar, komunikan dapat diarahkan sekehendak kita. Karena behaviorisme amat mempengaruhi model ini (Defleur dalam Rakhmat, 2016: 114).

\section{Analisis Variabel Efektivitas Komunikasi Dakwah}

Pertama keterbukaan, bahwa dari 172 responden, 44,2\% setuju bahwa Ustadz memberikan keleluasan santri untuk menyampaikan keluhan selama di Pondok, dan 52,9\% sangat setuju bahwa Ustadz memberikan keleluasan santri untuk menyampaikan keluhan selama di Pondok. Kesimpulannya, mayoritas responden setuju bahwa Ustadz memberikan keleluasan santri untuk menyampaikan keluhan selama di Pondok. 
Agus Sudiansyah

Selanjutnya untuk pernyataan kedua, yakni "Anda diperbolehkan memberikan masukan yang baik kepada pesantren" diketahui dari sebanyak dari 172 responden, 54,7\% setuju bahwa Anda diperbolehkan memberikan masukan yang baik kepada pesantren, dan 42,4\% sangat setuju bahwa anda diperbolehkan memberikan masukan yang baik kepada pesantren. Kesimpulannya, mayoritas responden setuju bahwa anda diperbolehkan memberikan masukan yang baik kepada pesantren.

Kedua Supportiveness (saling mendukung), berdasarkan hasil penelitian terhadap 172 santri Pondok Pesantren Madrasatul Qur an Tebuireung Jombang , mengenai penilaian responden terhadap pernyataan "Anda merasa Teman-teman selalu mendukung dalam berbuat kebaikan", diketahui sebesar 93 responden menyatakan setuju, 74responden menyatakan sangat setuju, dan 5 responden tidak ada tanggapan.

Selanjutnya untuk pernyataan ke dua yakni” Ustadz yang sukses di Pesantren mendukung anda bersikap baik dalam berprilaku", diketahui dari sebanyak 172 responden yang mengisi kuesioner, sebesar 61 responden diantarnya menjawab setuju, 106 responden menyatakan sangat setuju, 5 responden tidak memberikan tanggapan.

Selanjutnya untuk pernyataan ke tiga yakni” Ustadz dan pengurus selalu mendukung anda agar menjadi lebih baik" diketahui dari sebanyak 172 responden yang mengisi kuesioner, sebesar 56 responden diantarnya menjawab setuju, 110 responden menyatakan sangat setuju, 5 responden tidak memberikan tanggapan.

Ketiga Positiveness ( saling bersikap positif), Berdasarkan hasil penelitian terhadap 172 santri Pondok Pesantren Madrasatul Qur an Tebuireung Jombang, mengenai penilaian responden terhadap pernyataan "Melihat Ustadz yang sukses di Pesantren mendukung anda bersikap optimis dan positif', diketahui sebesar 59 responden menyatakan setuju, 108 responden menyatakan sangat setuju, dan 2,9\% responden tidak ada tanggapan.

Selanjutnya untuk pernyataan ke dua yakni" Ustadz dan pengurus selalu memberikan pemikiran yang positif terhadap anda" diketahui dari sebanyak 172 responden yang mengisi kuesioner, sebesar 57 responden diantarnya menjawab setuju, 110 responden menyatakan sangat setuju, 5 responden tidak memberikan tanggapan.

Selanjutnya untuk pernyataan ke tiga yakni" dengan banyaknya teman yang sukses mendukung anda bersikap optimis dan positif' diketahui dari sebanyak 172 responden yang mengisi kuesioner, sebesar 91 responden diantarnya menjawab setuju, 76 responden menyatakan sangat setuju, 5 responden tidak memberikan tanggapan.

Keempat Emphaty (yaitu memahami sifat orang lain), Berdasarkan hasil penelitian terhadap 172 santri Pondok Pesantren Madrasatul Qur an Tebuireung 
Jombang, mengenai penilaian responden terhadap pernyataan "Beragamnya latar belakang santri (berbeda suku dan bahasa) menyebabkan anda memahami perbedaan sifat antara anda dengan orang lain",diketahui sebesar 87 responden menyatakan setuju, 80 responden menyatakan sangat setuju, dan 5 responden tidak ada tanggapan.

Selanjutnya untuk pernyataan ke dua yakni” Dengan adanya perbedaan kondisi sosial santri, menyebabkan saya bisa ber empaty pada orang lain" diketahui dari sebanyak 172 responden yang mengisi kuesioner, sebesar 95 responden diantarnya menjawab setuju, 72 responden menyatakan sangat setuju, 5 responden tidak memberikan tanggapan.

Kelima Equality (kesetaraan), Berdasarkan hasil penelitian terhadap 172 santri Pondok Pesantren Madrasatul Qur an Tebuireung Jombang, mengenai penilaian responden terhadap pernyataan "Diterapkan kemandirian (Mencuci sendiri, mengantri makan, dan mengantri disegala hal) menjadikan diri saya sama dengan orang lain tidak ada yang kaya dan tidak ada yang miskin", diketahui sebesar 2 responden kurang setuju, 81 responden menyatakan setuju, 84 responden menyatakan sangat setuju, dan 5 responden tidak ada tanggapan.

Selanjutnya untuk pernyataan ke dua yakni” Ketika diwajibkannya shalat berjama'ah santri merasa sama dihadapan Allah" diketahui dari sebanyak 172 responden yang mengisi kuesioner, 2 responden menjawab kurang setuju, sebesar 95 responden diantarnya menjawab setuju, dan 70 responden menyatakan sangat setuju, 5 responden tidak memberikan tanggapan.

Selanjutnya untuk pernyataan ke tiga yakni” Semua santri diperlakukan sama, walaupun dalam setatus berbeda, dalam segala hal" diketahui dari sebanyak 172 responden yang mengisi kuesioner, sebesar 74 responden diantarnya menjawab setuju, dan 93 responden menyatakan sangat setuju, 5 responden tidak memberikan tanggapan.

Keenam Penyampaian syari'at Keislaman, Berdasarkan hasil penelitian terhadap 172 santri Pondok Pesantren Madrasatul Qur an Tebuireung Jombang, mengenai penilaian responden terhadap pernyataan "Dengan pendalaman ilmu Aqidah yang diberikan menjadikan saya lebih baik dalam beribadah (baik ibadah mahdoh maupun ghoiru mahdoh)", diketahui sebesar, 72 responden menyatakan setuju, 94 responden menyatakan sangat setuju, dan 5 responden tidak ada tanggapan.

Selanjutnya untuk pernyataan ke tiga yakni" Dengan pendalaman Taswauf yang diberikan menjadikan saya lebih baik dalam memahami kehidupan yang lebih baik." diketahui dari sebanyak 172 responden yang mengisi kuesioner, 1 responden kurang setuju sebesar 80 responden diantarnya menjawab setuju, dan 86 responden menyatakan sangat setuju, 5 responden tidak memberikan tanggapan.

Selanjutnya untuk pernyataan ke tiga yakni" Dengan pendalaman kajian 
Agus Sudiansyah

Syiroh Nabawiah yang diberikan menjadikan saya lebih memahami apa yang pernah dilakukan dalam kehidupan Rosul dan para Sahabat sehingga saya tanamkan pada diri saya sendiri" diketahui dari sebanyak 172 responden yang mengisi kuesioner, sebesar 95 responden diantarnya menjawab setuju, dan 72responden menyatakan sangat setuju, 5 responden tidak memberikan tanggapan.

\section{Analisis Variabel Pembinaan Akhlak.}

Pertama Pelatihan kebiasaan untuk berakhlak mulia dan terpuji, Berdasarkan hasil penelitian terhadap 172 responden dapat diketahui bahwa lebih dari setengah jumlah keseluruhan responden tersebut atau lebih tepatnya sebesar 98 responden menjawab sangat setuju terhadap pernyataan "Saya dipesantren diatih untuk berakhlak mulia dan memiliki kebiasaan terpuji dengan mengikuti sunnah Nabi". Selanjutnya diketahui sebesar masing-masing 69 responden menyatakan setuju dan tidak mengisi 5 responden.

Selanjutnya untuk pernyataan ke dua yakni" saya dipesantren dilatih dan dibiasakan menghargai diri sendiri”, diketahui dari sebanyak 172 responden yang mengisi kuesioner, sebesar 80 responden diantarnya menjawab setuju, dan 86 responden menyatakan sangat setuju, 5 responden tidak memberikan tanggapan.

Selanjutnya untuk pernyataan ke tiga yakni" Saya dipesantren dilatih dan dibiasakan menghormati orang tua dengan tutur kata yang baik (tidak keras suranya, dan lembut), mencium tangan sebagai penghormatan", diketahui dari sebanyak 172 responden yang mengisi kuesioner, 1 responden menjawab kurang setuju, sebesar 50 responden diantarnya menjawab setuju, dan 115 responden menyatakan sangat setuju, 5 responden tidak memberikan tanggapan.

Selanjutnya untuk pernyataan ke empat yakni" Di pesantren anda dilatih dan dibiasakan menghormati guru sebagai pewaris para Nabi, dengan tidak membantah, mendengarkan nasihatnya, menjalankan ajaran baik yang diberikan, serta mencium tangannya", diketahui dari sebanyak 172 responden yang mengisi kuesioner, sebesar 72 responden diantarnya menjawab setuju, dan 92 responden menyatakan sangat setuju, 5 responden tidak memberikan tanggapan.

Selanjutnya untuk pernyataan ke lima yakni" Dipesantren saya dilatih dan dibiasakan bebrbuat baik terhadap teman, dengan saling menghormati, dan saling membantu dalam kebaikan", diketahui dari sebanyak 172 responden yang mengisi kuesioner, sebesar 70 responden diantarnya menjawab setuju, dan 97 responden menyatakan sangat setuju, 5 responden tidak memberikan tanggapan.

Selanjutnya untuk pernyataan ke enam yakni" Di pesantren santri dilatih dan dibiasakan selalu menghormati tetangga, dengan menghormati asrama yang bersebelahan", diketahui dari sebanyak 172 responden yang mengisi kuesioner, 3 responden menjawab kurang setuju, sebesar 74 responden diantarnya menjawab setuju, dan 90 responden menyatakan sangat setuju, 5 responden tidak 
memberikan tanggapan.

Selanjutnya untuk pernyataan ke tujuh yakni" Di pesantren saya dilatih dan dibiasakan menghormati masyarakat sekitar, dengan ikut serta membantu masyarakat apabila diperlukan”, diketahui dari sebanyak 172 responden yang mengisi kuesioner, , sebesar 91 responden diantarnya menjawab setuju, dan 80 responden menyatakan sangat setuju, 5 responden tidak memberikan tanggapan.

Selanjutnya untuk pernyataan ke delapan yakni" Di pesantren saya dilatih dan dibiasakan menjaga lingkungan, dengan membuang sampah pada tempatnya, melaksankan tugas piket, dan ikut serta dalam gotong royong kebersihan", diketahui dari sebanyak 172 responden yang mengisi kuesioner, sebesar 79 responden diantarnya menjawab setuju, dan 78 responden menyatakan sangat setuju, 5 responden tidak memberikan tanggapan.

Selanjutnya untuk pernyataan ke sembilan yakni" Di pesntren anda diwajibkan untuk sholat berjama'ah dimasjid, shaum sunnah senin kamis, berdzikir dan ber istigfar kepada Allah SWT', diketahui dari sebanyak 172 responden yang mengisi kuesioner, sebesar 57 responden diantarnya menjawab setuju, dan 110 responden menyatakan sangat setuju, 5 responden tidak memberikan tanggapan.

Kedua Pembentukan pribadi, sikap dan mental, Berdasarkan hasil penelitian terhadap 172 responden dapat diketahui bahwa lebih dari setengah jumlah keseluruhan responden tersebut atau lebih tepatnya sebesar 109 responden menjawab sangat setuju terhadap pernyataan "Dipesantren pribadi diri saya dibentuk agar senantiasa ber iman Kepada Allah SWT, dan beribadah". Selanjutnya diketahui sebesar masing-masing 58 responden menyatakan setuju, dan tidak mengisi 5 responden.

Selanjutnya untuk pernyataan ke dua yakni" di pesantren anda dibentuk menjadi sorang yang bersikap mulia, dengan diarahkan terus memahami isi kandungan Al-Qur an", diketahui dari sebanyak 172 responden yang mengisi kuesioner, sebesar 82 responden diantarnya menjawab setuju, dan 85 responden menyatakan sangat setuju, 5 responden tidak memberikan tanggapan.

Selanjutnya untuk pernyataan ke tiga yakni” di pesantren anda dibentuk menjadi sorang yang bersikap mulia, dengan selalu bersyukur kepada Allah", diketahui dari sebanyak 172 responden yang mengisi kuesioner, sebesar 78 responden diantarnya menjawab setuju, dan 89 responden menyatakan sangat setuju, 5 responden tidak memberikan tanggapan.

Selanjutnya untuk pernyataan ke empat yakni" di pesantren saya dibentuk menjadi sorang yang bersikap mulia, dengan selalu bertawakal kepada Allah", diketahui dari sebanyak 172 responden yang mengisi kuesioner, sebesar 74 responden diantarnya menjawab setuju, dan 93 responden menyatakan sangat setuju, 5 responden tidak memberikan tanggapan.

Selanjutnya untuk pernyataan ke lima yakni" di pesantren anda dibentuk 
Agus Sudiansyah

menjadi sorang yang bersikap mulia, dengan selalu bersabar dalam menjalani hidup.”, diketahui dari sebanyak 172 responden yang mengisi kuesioner, sebesar 86 responden diantarnya menjawab setuju, dan 81 responden menyatakan sangat setuju, 5 responden tidak memberikan tanggapan.

Selanjutnya untuk pernyataan ke enam yakni" di pesantren anda dibiasakan hidup mandiri dalam menjalani kebutuhan sehari-hari, dan menjalani setiap aturan yang berlaku", diketahui dari sebanyak 172 responden yang mengisi kuesioner, sebesar 80 responden diantarnya menjawab setuju, dan 87 responden menyatakan sangat setuju, 5 responden tidak memberikan tanggapan.

Ketiga Pembentuk Kerohanian yang Luhur, Berdasarkan hasil penelitian terhadap 172 responden dapat diketahui bahwa lebih dari setengah jumlah keseluruhan responden tersebut atau lebih tepatnya sebesar 80 responden menjawab sangat setuju terhadap pernyataan "Di pesantren saya selalu diberikan pemahaman yang dalam, yang berkaitan dengan iman Kepada Allah, malaikatmalaikat, para Anbiya, Al-Qur an, Hari Akhir, serta Qodo dan qodar.”. Selanjutnya diketahui sebesar masing-masing 77 responden menyatakan setuju, dan tidak mengisi 5 responden.

Selanjutnya untuk pernyataan ke dua yakni" Di pesantren saya dibentuk dan dingatkan agar selalu berprasangka baik pada Allah", diketahui dari sebanyak 172 responden yang mengisi kuesioner, sebesar 86 responden diantarnya menjawab setuju, dan 81 responden menyatakan sangat setuju, 5 responden tidak memberikan tanggapan. Hasil tersebut bisa dilihat pada tabel 5.36 di abwah ini..

Selanjutnya untuk pernyataan ke tiga yakni" Di pesantren saya dibentuk dan dingatkan agar selalu memilki rasa takut pada Allah SWT.", diketahui dari sebanyak 172 responden yang mengisi kuesioner, sebesar 78 responden diantarnya menjawab setuju, dan 89 responden menyatakan sangat setuju, 5 responden tidak memberikan tanggapan. Hasil tersebut bisa dilihat pada tabel 5.37 di abwah ini.

\section{Analisis Variabel Akhlaq Santri.}

Pertama Akhlak santri kepada Allah SWT, Berdasarkan hasil penelitian terhadap 172 responden dapat diketahui bahwa lebih dari setengah jumlah keseluruhan responden tersebut atau lebih tepatnya sebesar 72 responden menjawab sangat setuju terhadap pernyataan "Anda merasa semua yang anda kerjakan karena beribadah kepada Allah SWT”. Selanjutnya diketahui, 3 responden kurang setuju, sebesar 92 responden menyatakan setuju dan tidak mengisi 5 responden.

Selanjutnya untuk pernyataan ke dua yakni" Semenjak saya mesantren di MQ Tebuireung sikap anda berubah menjadi orang yang bersyukur, bertawakal, serta tabah dan sabar pada Allah SW'”, diketahui dari sebanyak 172 responden yang mengisi kuesioner, sebesar 75 responden diantarnya menjawab setuju, dan 97 responden menyatakan sangat setuju, 5 responden tidak memberikan 
tanggapan.

Kedua Akhlak Pada makhluk Allah SWT, Berdasarkan hasil penelitian terhadap 172 responden dapat diketahui bahwa lebih dari setengah jumlah keseluruhan responden tersebut atau lebih tepatnya sebesar 83 responden menjawab sangat setuju terhadap pernyataan "Semenjak saya mesantren di MQ Tebuireung sikap anda berubah menjadi orang yang pandai berbuat baik pada diri sendiri, orang tua, guru, teman dan lingkungan hidup". Selanjutnya diketahui, 1 responden kurang setuju, sebesar 3 responden menyatakan setuju dan tidak mengisi 5 responden.

Selanjutnya untuk pernyataan ke dua yakni" Semenjak saya mesantren di MQ Tebuireung sikap anda berubah menjadi orang yang pandai mengikuti sunnah Nabi, Sahabat Nabi, dan Para Ulama", diketahui dari sebanyak 172 responden yang mengisi kuesioner, sebesar 69 responden diantarnya menjawab setuju, dan 98 responden menyatakan sangat setuju, 5 responden tidak memberikan tanggapan.

Pengujian Hipotesis $\mathrm{H} 1$ dan $\mathrm{H} 2$ dengan Uji t. Pertama Pengujian Hipotesis Pertama (H1), Diketahui nilai Sig, untuk pengaruh X1 terhadap Y adalah sebesar 0,157>0,05 dan nilai t hitung 1,420< t tabel 1,97410, sehingga dapat disimpulkan bahwa $\mathrm{H} 1$ ditolak yang berarti tidak terdapat pengaruh $\mathrm{H} 1$ terhadap Y.

Kedua Pengujian Hipotesis Kedua (H2), Diketahui nilai Sig, untuk pengaruh X1 terhadap $\mathrm{Y}$ adalah sebesar $0,000<0,05$ dan nilai t hitung 3,36 $>\mathrm{t}$ tabel 1,97410, sehingga dapat disimpulkan bahwa $\mathrm{H} 2$ diterima yang berarti terdapat pengaruh $\mathrm{H} 2$ terhadap $\mathrm{Y}$.

Pengujian Hipotesis H3 dengan Uji F

Berdasarkan output di atas diketahui nilai signifikansi untuk pengaruh X1 dan $\mathrm{X} 2$ secara simultan terhadap $\mathrm{Y}$ adalah sebesar $0,000<0,05$ dan nilai $\mathrm{F}$ hitung 18,009 > 3,05, sehingga dapat disimpulkan bahwa H3 diterima yang berarti terdapat pengaruh X1 dan X2 secara simultan terhadap Y.

Koefesien Diterminasi

Berdasarkan output di atas diketahui nilai $\mathrm{R}$ Square sebesar 0,424, hal ini mengandung arti bahwa pengaruh variabel X1 dan X2 secara simultan terhadap variabel Y adalah sebesar 42,4\%. Berdasarkan nilai kekuatan hubungan antar variabel (Sugiyono, 2008:54), maka dengan angka koefisien sebesar 0,424 menunjukan kekuatan pengaruh antara variabel efektivitas komunikasi dan dan pembinaan akhlak dengan akhak santri sedang tapi pasti.

Uji Korelasi Variabel

Priyato (2008:53) menyebutkan analisis korelasi sedernana atau bivariate correlation digunakan untuk mengetahui keeratan hubungan antara dua atau lebih variabel dan untuk mengetahui arah hubungan yang terjadi. Tabel 5.44 yaitu hasil analisis korelasi sederhana (r) menunjukkan korelasi antara 
Agus Sudiansyah

komunikasi dakwah yang efektif dan pembinaan akhlak dengan akhlak santri adalah 0,332 dan $0,417=0,749$ (Sugiyono, 2008:54).

\section{PENUTUP}

Pertama ringkasan, berdasrkan hasil penelitian, maka dapat disimpulkan bahwa efektivitas komunikasi dakwah dan pembinaan akhlak di Pesantren Madrasatul Qur an Tebuireung Jombang memiliki korelasi yang kuat dan pengaruh yang sedang terhadap akhlak santri. Pengaruh tersebut bersifat positif sehingga semakin efektif Komunikasi dakwah dan pembinaan akhlak semakin baik pula akhlak santri di Pesantren Madrasatul Qur an Tebuireung Jombang.

Dalam rangka meningkatkan efektivitas komunikasi dakwah dan pembinaan akhlak, perlu dilakukan optimalisasi program-program komunikasi dakwah yang sudah ada, seperti dakwah bil lisan, dakwah bil hal, dan dakwah bil uswah, pada setiap masing-masing pengurus. Selain itu juga perlu dibentuk tim pembinaan akhlak yang sekara khusus membina santri, dan Dalam rangka meningkatkan akhlak santri, perlu dilakukan optimalisasi program-program seperti, tausiah rutinan, pengkajian kitab akhlak rutin.

\section{DAFTAR PUSTAKA}

Aminulloh, A. (2010). Komunikasi Politik Dakwah Partai Keadilan Sejahtera pada Pemilu legislatif 2009. Jurnal Ilmu Komunikasi, 8(1).

Ariyanto, B. dkk. (2019). Strategi Komunikasi Dakwah dalam Pembinaan Mental

Narapidana. Sahafa Journal of Islamic Communication, 1(2).

Bachtiar, M. A. (2013). Dakwah Kolaboratif: Model Alternatif Komunikasi Islam Kontemporer. Jurnal Komunikeasi Islam, 3(1)

Kiryantono. (2012), Komunikasi Antar Manusia. Jakarta: Profesional Books.

Ma'arif, B.S. (2009). Pola Komunikasi Dakwah KH. Abdullah Gymnastiar dan KH. Jalaluddin Rakhmat. Mimbar. Mimbar: Jumal Sosial dan Pembangunan, 25(2).

Marimba, A. D. (1989), Pengantar Filsafat Pendidikan Islam, Bandung: Al Ma'arif. Ilmu.

Markarma, A. (2014). Komunikasi Dakwah Efektif dalam Perspektif Alquran. Hunafa: Jurnal Studia Islamika, 11(1).

Maureen, M. (1996), Inforelief, United States Of Amerika.

Moh. Ardani. (2005), Akblak-Tasawuf Nilai-nilai akhlak/ Budi Pekerti dalam ibadat \&o taswauf. Jakarta: CV Karya Mulia.

Muhtadi, A. S. (2012). Komunikasi Dakwah: Teori, Pendekatan, dan Aplikasi. Bandung: Simbiosa Rekatama Media

Mursyidah, D. (2010). Membangun Komunikasi Dakwah Melalui Media Massa. Media Akademika, 25(3).

Mursyidah, D. (2012). Disfungsi Tradisi Lisan Melayu Jambi Sebagai Media 
Efektivitas Komunikasi Dakwah di Pesantren MQ dalam Merubah Akhlak Santri

Komunikasi Dakwah. Tajdid, 11(2).

Permana, R. (2013). Strategi Komunikasi Dakwah Band Wali dalam Lagu Cari Berkah. Jurnal Komunikasi Islam, 3(1).

Rachmiatie, A. (2002). Paradigma Baru Dakwah Islam: Perspektif Komunikasi Massa. Mediator, 3(1).

Rajab, M. (2014). Dakwah dan Tantangannya dalam Media Teknologi Komunikasi. Tabligh, 15(1).

Rakhmat, J. (2005). Psikologi komunikasi. Bandung: Remadja Rosdakarya, 2005

Sugiyono, D. (2008). Metode penelitian bisnis. Bandung: Pusat Bahasa Depdiknas.

Suharto, S. (2013). Urgensi Komunikasi Politik Dakwah. Tabligh, 14(1).

Syukur, A. (2014). Dinamika Dakwah dalam Komunikasi dan Penyiaran Islam; Pendekatan Historisasi, Formulasi dan Aplikasi. Bina Al Ummah, 9(2). 
Agus Sudiansyah 